\title{
Employee Satisfaction and the Role of Motivation: A Study of a Super-specialty Hospital
}

Jharna Bajpai

\section{ABSTRACT}

Employee satisfaction plays a role in motivation and ultimately, overall productivity and bottomline results. Employees who are more satisfied in their positions have more reasons to work hard and contribute to a shared work ethic that encourages others to do the same. Likewise, drops in productivity may stem from low levels of worker satisfaction. This paper throws light on the role of motivation and employee satisfaction in a super specialty hospital. A questionnaire pertaining to various motivations related questions was distributed to various employees. The sample size was 118 and a combination of descriptive and exploratory research methodology was used. Nominal scale and likert five points scaling was used for measuring the satisfaction level. Data were analyzed using the Statistical Package for the Social Science (SPSS) software program version-16 and conclusions were drawn. Approximately 53\% of the employees were satisfied with the promotion policy. Sixty percent of respondents were satisfied with the working atmosphere of the organization and $32 \%$ were satisfied with the remuneration they are receiving. This paper discusses such more aspects which play a role in motivation and suggest solutions to make employees satisfied with their job.

Keywords: Employee satisfaction, Hospital, Human resource management, Job satisfaction, Motivation.

How to cite this article: Bajpai J. Employee Satisfaction and the Role of Motivation: A Study of a Super-specialty Hospital. Int J Res Foundation Hosp Healthc Adm 2015;3(2):65-68.

\section{Source of support: Nil}

Conflict of interest: None

\section{INTRODUCTION}

Human resources are the most important among all the resources an organization owns that can lead the organization to long-lasting success. Retention of efficient and experienced workforce in an organization is very crucial in overall performance of an organization. Motivated employees can help to make an organization

\section{Quality Executive}

Department of Quality Assurance, Bhagwan Mahaveer Cancer Hospital and Research Center, Jaipur, Rajasthan, India

Corresponding Author: Jharna Bajpai, Quality Executive Department of Quality Assurance, 59 Devi Path, JLN Marg, Near Soni Hospital, Jaipur, Rajasthan, India, Phone: +918290598300 e-mail: drjharnabajpai@gmail.com competitively more value added and profitable, ${ }^{1}$ whereas dissatisfied employees tend to perform below their capabilities, result in high turnover of staff and leave their jobs relatively quickly, and are not very likely to recommend your organization as an employer. ${ }^{2}$ Motivational factors play an important role in increasing employee job satisfaction which results in improving organizational performance.

This study throws light on the level of employee satisfaction and the role of motivation in the less satisfied ones of a super specialty hospital.

\section{MATERIALS AND METHODS}

\section{Research Methodology}

The present study was conducted among employees of a super specialty hospital. The period of this study was 2 months (August to October 2014). The total number of questionnaires distributed was 150, out of which, 118 found to be completely filled. The response rate was $78.6 \%$.

\section{Tools and Techniques}

Respondents were selected by 'convenient sampling' technique. The researcher has used combination of exploratory and descriptive research. The research tool was a structured, self-administered bilingual questionnaire. The instrument is validated and reliable as it is taken from standard survey resource of employee satisfaction. The questions are about the appreciation and the feeling of self-fulfillment they get or do not get from their work. Questions are on money, benefits, compensation, communication, job security, appreciation from managers, recognition, training and development and promotion. Nominal scale and likert five points scaling was used for measuring the satisfaction level. The rating was done as following: 5 = Highly satisfied, $4=$ satisfied, $3=$ neutral, $2=$ unsatisfied, 1 = highly unsatisfied.

\section{Ethical Considerations}

The institutional ethical committee approved methodology and data collection procedure of the study. Participation was purely voluntary for the respondents. An employee having age above 18 years was included in 
the study. No pressure or inducement of any kind was applied to encourage an individual to become included in the study. Before participation, all employees were notified about the study's aim, objectives and methods. Any employee had the right to abstain from participation or to terminate participation at any time. The identity of employees from whom information is obtained in the course of the study was kept strictly confidential. No information revealing the identity of any individual was included in the final report or in any other communication prepared in the course of the study.

\section{STATISTICAL METHODS}

Data were analyzed using the Statistical Package for the Social Science (SPSS) software program version-16. First, the mean, median, mode, standard deviation was calculated, and then test of significance applied to calculate the $\mathrm{p}$-value at the $95 \%$ confidence interval.

\section{RESULTS}

Fifty-five percent of the employees were males and the rest were females. Approximately, 34\% of the employees fall in the age group 40 to 49 . Thirty-six percent of the respondents have a work experience greater than 10 years (Table 1). The employees who participated in this study comprises of 59 respondents from Nursing staff, 18 respondents from technical staff and 41 respondents from administrative staff (Table 2). Fiftythree percent of the respondents were satisfied with the promotion polices. Sixty percent of respondents were satisfied with the working atmosphere of the organization. Approximately $62 \%$ employees were highly satisfied with the decision making authority given to them. Fourteen percent employees were unsatisfied with the communication from management related to hospital updates. Seventy-seven percent employees were satisfied with the trainings provided by the hospital and $65 \%$ employees were satisfied with the facilities given by the organization (Table 3). Fifty-eight percent of the employees were not satisfied in terms of receiving personal satisfaction from their job. Seventyone percent employees agreed upon recognizing and acknowledging their work by the organization (Table 4). Cross tables were made and test of significance was applied to various determinants. It showed borderline statistical significant association between training provided by the organization and respondents of age 20 to 29 ( $p<0.05$ ). There occurred a statistical significant association between the administrative staff and facilities given by the organization $(\mathrm{p}<0.01)$. The employees who have spent more than 10 years in this organization showed a statistical significant relationship with the overall job security $(\mathrm{p}<0.05)$.

Table 1: Sociodemographic distribution of respondents in a Super-specialty Hospital $(n=118)$

\begin{tabular}{lll}
\hline Variables & Frequency & Percentage \\
\hline Gender & 65 & \\
Males & 53 & 55.08 \\
Females & & 44.92 \\
Age & 18 & \\
$20-29$ & 26 & 15.25 \\
$30-39$ & 40 & 22.03 \\
$40-49$ & 34 & 33.90 \\
50 and above & & 28.81 \\
Work experience & 20 & \\
$0-2$ years & 23 & 16.95 \\
2-5 years & 33 & 19.49 \\
5-10 years & 42 & 27.97 \\
More than 10 years & & 35.59 \\
\hline
\end{tabular}

Table 2: Percentage of the type of staff who participated in this study $(n=118)$

\begin{tabular}{ll}
\hline Type of staff & Percentage \\
\hline Nursing & 50 \\
Technical & 15 \\
Administrative & 35 \\
\hline
\end{tabular}

Table 3: Frequency of responses to various parameters of motivation part $(n=118)$

\begin{tabular}{|c|c|c|c|c|c|c|}
\hline $\begin{array}{l}\text { Sl. } \\
\text { no. }\end{array}$ & Parameter & $\begin{array}{l}\text { Highly } \\
\text { satisfied }\end{array}$ & Satisfied & Neutral & Unsatisfied & $\begin{array}{l}\text { Highly } \\
\text { unsatisfied }\end{array}$ \\
\hline 1. & Team spirit of your team members & 28 & 44 & 14 & 30 & 2 \\
\hline 2. & Your direct supervisor as a positive role model & 21 & 32 & 18 & 41 & 6 \\
\hline 3. & With your overall job security & 39 & 55 & 2 & 14 & 8 \\
\hline 4. & With the work environment & 25 & 46 & 17 & 24 & 6 \\
\hline 5. & With the salary provided by the organization & 17 & 21 & 7 & 48 & 25 \\
\hline 6. & With decision-making authority & 44 & 30 & 6 & 21 & 17 \\
\hline 7. & With promotion policy & 39 & 24 & 3 & 42 & 10 \\
\hline 8. & With opportunity to utilize your skills and talents & 19 & 20 & 12 & 43 & 24 \\
\hline 9. & $\begin{array}{l}\text { With communication from management related to hospital } \\
\text { updates }\end{array}$ & 40 & 46 & 15 & 11 & 6 \\
\hline 10. & With the training provided by the hospital & 38 & 53 & 8 & 14 & 5 \\
\hline 11. & With the facilities given by organization & 34 & 43 & 14 & 15 & 12 \\
\hline
\end{tabular}


Table 4: Percentage of responses to various parameters of motivation part $(n=118)$

\begin{tabular}{rlll}
\hline Sl. & Parameter & Yes (\%) & No (\%) \\
no. & Does your job give you a sense of personal satisfaction? & 58 \\
\hline 2. & Organization recognizes and acknowledges your work & 71 & 39 \\
\hline
\end{tabular}

\section{DISCUSSION}

Motivation is going to work if the right person with suitable skills is made responsible for the job or otherwise it will be the wastage of resources and time, and lead to job dissatisfaction. ${ }^{3}$ Employee job satisfaction (EJS) is the feelings and thoughts of employees about their work and place of work. In result, job satisfaction is all about to satisfy one's needs in working place. ${ }^{4}$ Job satisfaction can be typically defined as the emotional reaction of an employee toward work, on the basis of comparing the actual results and the expected ones. ${ }^{5}$ The process of motivation usually starts with someone recognizing an unsatisfied need. Then, a goal is established to be reached and that way to satisfy the need. Motivation is the driving force in any individual which moves him (or her) to act in a certain way. It is what drives your employees to give their best for your business. ${ }^{6}$ Find out what motivates man, touch that button to turn the key that makes men achieve. ${ }^{7}$ Every organization's work culture is different, the needs of the employees should be understood and they should be imparted with different trainings, personal development and an atmosphere for freely expression of ideas which could be adopted for the betterment of the organization which in turn enhances productivity. Incentives, rewards and recognitions are the prime factors that impact on employee motivation. According to Baum (1995), HR progress through education, training, and development of employees at all levels which is a vital component in sustaining the industry's competitiveness in the international arena. ${ }^{8}$ According to Herzberg, money is listed as a hygiene factor which is likely to cause job dissatisfaction. Salary is a thing that is expected to be at a certain level and comparable to the amount of work the employee does. Only 32\% employees were satisfied in terms of remuneration they are receiving which means that the salary is not meeting the expectations of the employees which could hamper productivity in the long run. The management should take into account this factor, because when it is improved, it can raise the motivation of the employees which in turn enhances the productivity. Seventy-one percent employees agreed upon recognizing and acknowledging their work by the organization. This is in consistent with the study conducted by Gupta and Garg. ${ }^{9}$ Fifty-eight percent of the employees were unsatisfied from their job in terms of personal satisfaction. Seventy-one percent employees agreed upon recognizing and acknowledging their work by the organization. Fifty-three percent of the respondents were satisfied with the promotion polices. Administration should take steps to gain more satisfaction of the employees in terms of promotion. Star employee of the month for nursing, technical and administrative staff could be a solution and these recognitions shall be attached in the employees' personal files, and, hence, promotions shall be given by keeping in mind these recognitions. Eighty percent of respondents were satisfied with their overall job security which is in contrast to the study conducted by Parvin and Kabir, who found $61 \%$ satisfaction. ${ }^{10}$ Employees who feel their future is successful in the organization work better than those who are insecure about it. Job security plays a factor of intrinsic motivation. Approximately $45 \%$ of respondents were satisfied with their direct supervisor as a positive role model. Herzberg listed this factor as hygiene factor which could cause job dissatisfaction. Relationship with the immediate supervisor and their outlook toward him/ her plays an important factor in job satisfaction because if the relationship between the immediate supervisor and the employee is cordial, lot of misunderstandings could be sorted out which in turn results in a positive atmosphere which ultimately motivates the employee. Communication is essential among peers and at different hierarchical level. The employees feel that someone is listening to their concerns, suggestions. The employees in this hospital are fairly satisfied with the communication inside the company. Only 33\% employees were highly satisfied with the opportunity to utilize their skills and talents. The management should take enough steps to provide them with a platform where the employees can express their views come up with recommendations and suggestions for improvement. Not many studies have been conducted in a hospital to measure the satisfaction levels of its employees. Research on the role of motivation in heathcare industry is still in infant stage. Future work to discover more such aspects may pave ways for many new ideas to gain productivity from the employees. 


\section{Questionnaire}

Sociodemographic details

- Name (optional)

- Gender

- Age (years)

- Work experience

- Type of staff

Parameters

- Team spirit of your team members 1

- Your direct supervisor as a positive role model 1

- With your overall job security

- With the work environment

- With the salary provided by the organization 1

- With decision-making authority 1

- With promotion policy

- With opportunity to utilize your skills and talents 1

- With communication from management 1 related to hospital updates

- With the training provided by the hospital 1

- With the facilities given by organization 1

- Does your job give you a sense of personal Yes - Male $\quad$ Female

- 20-29 years - 30-39 years - 40-49 years • 50 and above

- 0-2 years - 2-5 years - 5-10 years - More than 10 years

- Technical - Administration • Nursing staff satisfaction?

- Organization recognizes and acknowledges Yes your work

This questionnaire is prepared for assessing the satisfaction of employees in our hospital. Your cooperation will be highly appreciated. Your reply will be kept confidential. Therefore, please feel free to answer the questions. Please mark tick $(\sqrt{ })$ on the suitable response. Scale to measure satisfaction: 5 = Highly satisfied; 4 = Satisfied; $3=$ Neutral; $2=$ Unsatisfied and $1=$ Highly unsatisfied

\section{REFERENCES}

1. Danish RQ, Usman A. Impact of reward and recognition on job satisfaction and motivation: an empirical study from Pakistan. Int J Business and Management 2010;5(2):159-167.

2. Sinha E. A research work on employee satisfaction measurement with special reference to KRIBHCO, Surat. Int J Modern Engineering Res 2013;3(1):523-529.

3. Kaur A. Maslow's Need Hierarchy Theory: Applications and Criticisms. Global J Management and Business Studies 2013;3(10):1061-1064.

4. Rizwan M, Khan WM, Tariq HMA, Ghaffar A, Anjum MZ, Bajwa EU. Empirical study of Employee job Satisfaction. IOSR J Business Management; 2012. p. 29-35.

5. Mohammad SIS, Al-Zeaud HA, Batayneh AME. The relationship between transformational leadership and employees' satisfaction at Jordanian Private Hospitals. J Business and Economics Horizon 2011;5(2):35-46.

6. Stroh EC. Personnel motivation: strategies to stimulate employees to increase performance. Politeia 2001;20(2):59-74.

7. Kalburgi MJ, Dinesh GP. Motivation as a tool for productivity in public sector unit. Asian J Management Res; 2010. p. 147-152.

8. Bagri SC, Babu S, Kukreti M. Human resource practices in hotels: A study from the tourist state of Uttrakhand, India. Journal of Human Resources in Hospitality and Tourism 2010;9(3):286-299.

9. Gupta N, Garg K. Employees satisfaction and motivation: a study of hotel sarovar portico, Sahibabad, Ghaziabad. VSRD Int J Business and Management Res 2013;3:331-336.

10. Parvin MM, Kabir MMN. Factors affecting employee job satisfaction of pharmaceutical sector. Australian J Business and Management Res 2011;1(9):113-123. 